\title{
Potential and Current Requirements for the Cathodic Protection of Steel in Soils
}

\author{
W. J. Schwerdtfeger and O. N. McDorman
}

\begin{abstract}
Potentials of steel in 20 air-free soils varying in $\mathrm{pH}$ from 2.9 to 9.6 were determined in the laboratory. These data and the potential- $\mathrm{pH}$ relation for the hydrogen electrode were used in fixing the optimum potential for the cathodic protection of the steel against corrosion. The effectiveness of this potential for the cathodic protection of steel in soils was confirmed by weight-loss measurements on electrodes that were maintained at the selected potential in five corrosive soils. Cathodic polarization curves are interpreted in terms of the potential and current requirements for the cathodic protection of steel in soils.
\end{abstract}

\section{Introduction}

Cathodic protection of underground steel structures usually is accomplished by applying direct current of such magnitude that the structure assumes a certain potential with respect to a standard reference electrode. Experience with piping systems has indicated that the optimum potential for this protection is approximately $-0.85 \mathrm{v}$ referred to a copper-copper sulfate electrode [1]. ${ }^{1}$ As potentials are measured while the applied current is flowing, an indefinite IR drop between the reference electrode and the electrical boundary of the corrosion circuits may be included. Consequently, the true potential of the corroding surface is not known. Altbough underground structures maintained at this potential are probably not materially affected by corrosion, the theoretical and experimental basis for $-0.85 \mathrm{v}$ as applicable to all soil environments has never been stated.

By applying electrical theory to the behavior of galvanic couples, Mears and Brown [2] deduced that cathodic protection is achieved when the potentials of the local cathodes are brought by polarization to the open-circuit potential of the most anodic element. In soils, differences in potential exist on the surface of buried steel structures, in effect forming galvanic couples. The problem then is that of determining a critical potential generally applicable to steel in soils.

The concentration of ferrous ions in equilibrium with iron in water is very small in the alkaline range $[3,4,5]$. Gatty and Spooner [6] cite references indicating that the potential of iron in air-free solutions is a function of the hydrogen-ion concentration of the solution, the potential increasing in the anodic direction with increasing values of $\mathrm{pH}$. Consequently, it appears that the rate of corrosion of iron in a solution may be reduced to a negligible value by polarizing the surface of the metal to a potential corresponding to a $\mathrm{pH}$ value at which the concentration of ferrous ions is small. Although no exact relation would be expected between the potential of

\footnotetext{
1 Figures in brackets indicate the literature references at the end of this paper.
}

iron and hydrogen-ion concentration in air-free soils differing widely in composition, an approximate evaluation of the critical potential at which iron would be subject to negligible corrosion appears teasible. This requirement for cathodic protection may be subjected to experimental verification by maintaining weighed electrodes exposed to normal corrosion in soils at the selected potential for a considerable period of time.

\section{Potential of Steel in Air-free Soils}

Potentials of steel electrodes ${ }^{2}$ were measured in 20 air-free soils ranging in $\mathrm{pH}$ from 2.9 to 9.6 and in resistivity from 60 to $17,800 \mathrm{ohm}-\mathrm{cm}$. Each soil was finely ground and saturated with water, and then mechanically worked and carefully packed into a Lucite cylinder $1.75 \mathrm{in}$. (45 mm) inside diameter by 2 in. (51 mm) long. The steel electrode was a disk $1.73 \mathrm{in.}(44 \mathrm{~mm})$ in diameter by $0.125 \mathrm{in}$. (3.2 $\mathrm{mm}$ ) thick with machined surfaces. One surface of the disk after degreasing was scratched with $1 \mathrm{G}$ French emery paper. With this surface adjacent to the soil at one end of the cylinder while the other end rested on a flat surface, the disk was manually pressed with an oscillatory motion until the soil began to ooze out around the edge, indicating that good contact between steel and soil had been secured. After removing the excess soil from the edge of the disk and cylinder, molten asphalt was applied around the edge of the disk to hold it and to serve as an air seal. A circular piece of No. 16 mesh stainless steel screen with a 0.25 -in. (6.4-mm) hole in the center was pressed against the soil at the other end of the cylinder. Then molten asphalt was applied over this entire area excepting the hole, which permitted release of the soil pressure and served as an area of contact for the reference electrode. The soil cells were individually confined in a watersaturated atmosphere and removed only for such time as was required for daily potential measurements which were made with a potentiometer. The

${ }^{2}$ Composition of steel in percent: $0.23 \mathrm{C}, 0.58 \mathrm{Mn}, 0.003 \mathrm{P}, 0.025 \mathrm{~S}, 0.095 \mathrm{Si}$, $0.077 \mathrm{Cu}$ 
potentials of triplicate cells became relatively steady and varied less than $\pm 5 \mathrm{mv}$, indicating that oxygen had been effectively excluded or consumed by corrosion. Stabilization at the most anodic potentials occurred within a period of 10 days.

The values of the potentials of the steel electrodes in the different air-free soils versus the $\mathrm{pH}$ values of the corresponding soils are shown in figure 1. Each point represents the average of four potential measurements made on as many consecutive days after stabilization of the electrodes. The rather wide dispersion of the values for soils having approximately the same hydrogen-ion concentration results from the fact that the potential of steel in aqueous electrolytes is determined by the composition, as well as by the hydrogen-ion concentration of the electrolyte. The curve is similar to curves representing the potential of iron as a function of hydrogen-ion concentration in different aqueous electrolytes [6]. In fact, it may be considered as a composite of the potential$\mathrm{pH}$ curves for different salt solutions reported in the literature.

Corey and Finnegan [5] report that the hydrogenion concentration of waters in which iron is in equilibrium with ferrous hydroxide is between 8.3 and 9.6 , depending on the composition of the waters and other factors. Since the curve in figure 1 is a composite for various soils it would be reasonable to select a critical potential based on the average $\mathrm{pH}$ value reported in the literature, such as $\mathrm{pH} 9$. It will also be observed in figure 1 that at this value the potential curve for the standard hydrogen electrode at atmospheric pressure intersects the potential curve for steel. According to Holler [7] corrosion is reduced to a negligible amount at this point, since there is no difference of potential between the hydrogen and steel electrodes. The potential at this intersection, approximately $-0.77 \mathrm{v}$, therefore is considered as the protective potential. (This potential is equivalent to $-0.53 \mathrm{v}$. on the standard hydrogen scale).

\section{Properties of the Soils Used in the Study of Cathodic Protection}

The samples of soil for the study of cathodic protection were taken from five of the National Bureau of Standards soil-corrosion test sites. The soils vary considerably with respect to their physical properties and the composition of the water-soluble matter (table 1). All of these soils are severely corrosive toward ferrous metals, as is evidenced by their low resistivities. Specimens of 1.5 -in. $(38-\mathrm{mm})$ steel pipe of standard wall thickness 0.145 in. $(3.7 \mathrm{~mm})$ were perforated within 8 years in soil No. 64 .

\section{Experimental Methods}

The experimental corrosion cell in which the test electrode ${ }^{3}$ was subjected to corrosion by differential aeration is shown in figure 2. The cell was made

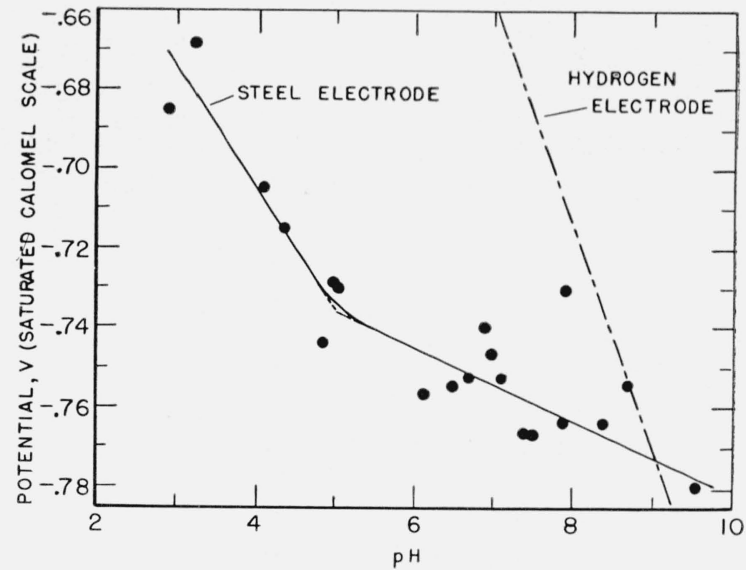

Figure 1. Relation between the potential of steel in air-free soils and the $\mathrm{pH}$ values of the soils

up with four Lucite sections. Differential aeration was accomplished by puddling half the soil of the top section and wetting the other half under a suction of $30 \mathrm{~cm}$ of mercury. The soil of the other three sections also was moistened under suction. The suction apparatus consisted of flasks fitted with buckner funnels of the fritted-glass type. After packing the puddled soil into one-half of the top section, the four sections were set up inside the funnels. Dry soil, previously passed through a No. 20 mesh sieve was packed into each section. Water dispensers that provided for uniform distribution of distilled water were set up over the dry soil of each section. The rate of moistening the soil was controlled by the degree of suction and by the characteristics of the soil. The perforated steel electrode (fig. 2) was the auxiliary anode, the perforations permitting air to pass through to the test electrode from the bottom of the cell. The stainless steel screen kept the soil intact. The component parts were held together by asphalt, which also served as a sealer. The

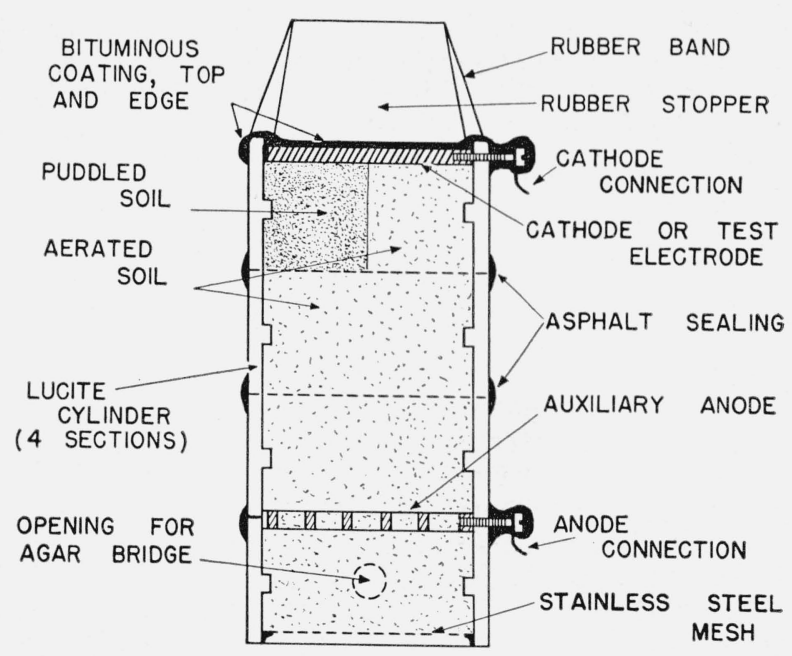

Figure 2. Details of experimental corrosion cell. 
TABLE 1. Properties of the soils

\begin{tabular}{|c|c|c|c|c|c|c|c|c|c|c|c|c|c|}
\hline \multicolumn{3}{|c|}{ Soil } & \multirow{2}{*}{$\mathrm{pH}$} & \multirow{2}{*}{$\begin{array}{l}\text { Resis- } \\
\text { tivity at } \\
60^{\circ} \mathrm{F}\end{array}$} & \multirow{2}{*}{$\begin{array}{l}\text { Aera- } \\
\text { tion } b\end{array}$} & \multirow{2}{*}{$\begin{array}{c}\text { Total } \\
\text { acidity } \\
(\text { Mg-eq/100 } \\
\text { g of soil) })^{\mathrm{c}}\end{array}$} & \multicolumn{7}{|c|}{$\begin{array}{l}\text { Composition of water extract-milligram } \\
\text { equivalents per } 100 \mathrm{~g} \text { of soil }\end{array}$} \\
\hline Number a & Type & Location of test site & & & & & $\begin{array}{c}\mathrm{Na}+\mathrm{K} \\
\text { as Na }\end{array}$ & $\mathrm{Ca}$ & $\mathrm{Mg}$ & $\mathrm{CO}_{3}$ & $\mathrm{HCO}_{3}$ & $\mathrm{Cl}$ & $\mathrm{SO}_{4}$ \\
\hline $\begin{array}{l}13 \ldots \\
60 \ldots \\
64 \ldots \\
78 \\
79\end{array}$ & $\begin{array}{l}\text { Hanford very fine sandy loam. } \\
\text { Rifle peat__. } \\
\text { Docas clay... } \\
\text { Caddo fine sandy loam- } \\
\text { Tidal marsh }\end{array}$ & $\begin{array}{l}\text { Bakersfield, Calif } \\
\text { Plymouth, Ohio } \\
\text { Cholame, Calif } \\
\text { Latex, Tex } \\
\text { Freeport, Tex...... }\end{array}$ & $\begin{array}{l}9.5 \\
2.9 \\
7.9 \\
4.5 \\
7.9\end{array}$ & $\begin{array}{c}\text { Ohm-cm } \\
290 \\
218 \\
62 \\
821 \\
324\end{array}$ & $\begin{array}{l}\mathrm{G} \\
\mathrm{P} \\
\mathrm{F} \\
\mathrm{P} \\
\mathrm{P}\end{array}$ & $\begin{array}{c}\mathrm{A} \\
297.4 \\
\mathrm{~A} \\
24.0 \\
\mathrm{~A}\end{array}$ & $\begin{array}{r}6.23 \\
2.91 \\
28.10 \\
1.06 \\
6.22\end{array}$ & $\begin{array}{r}0.09 \\
10.95 \\
2.29 \\
0.18 \\
.40\end{array}$ & $\begin{array}{r}0.13 \\
2.86 \\
0.76 \\
.31 \\
.31\end{array}$ & $\begin{array}{r}0.00 \\
.00 \\
.00 \\
.00 \\
.00\end{array}$ & $\begin{array}{r}1.12 \\
0.00 \\
.89 \\
.00 \\
3.42\end{array}$ & $\begin{array}{r}1.64 \\
0.00 \\
28.80 \\
0.82 \\
2.99\end{array}$ & $\begin{array}{r}3.76 \\
56.70 \\
0.26 \\
.74 \\
1.01\end{array}$ \\
\hline
\end{tabular}

a Soil number also refers to site number as specified in Bureau soil-corrosion tests.

b Aeration of soils: G, good; F, fair; P, poor.

A indicates absence of acidity because of alkaline reaction.

rubber band placed longitudinally around the cell applied pressure to the test electrode through the rubber stopper. Since the asphalt was pliable, this pressure assured contact between steel and soil. The only part of the test electrode subject to corrosion was the machined surface adjacent to the soil. The surface was prepared by degreasing and scratching with $1 \mathrm{G}$ French emery paper. The edge and top side were coated with a bitumastic compound. Electric connections to the electrodes were made through steel screws that had wires soldered to the heads. Potential measurements were made through an agar bridge at the lower side of the cell. The cell was stored in a friction top can containing a small quantity of water to keep the air saturated with moisture. The cell was placed above the water level and was not removed for the duration of the study. Wires from the electrodes were brought through holes in the side of the can. The can also was fitted with a hole for insertion of the agar bridge. When potential measurements were not being made, the bridge was removed and the hole was sealed.

Each cathodic protection test was of 60-days duration. Several cells were assembled with each soil, and cells for any one soil were operated concurrently. The corrosion rates in such a group of cells were reproducible within a standard error of about 8 percent. All the cells were permitted to react freely for a period of approximately 48 hours before applying protective currents. The weight losses that occurred during this period were calculated from cathodic and anodic polarization curves such as described by Holler [7] and Pearson [8]. The cathodic polarization curves also are interpreted in connection with the current required for protection, to be discussed later. Cathodic polarization data obtained at the conclusion of the 60-day period were similarly plotted. In obtaining the data it was found necessary to apply approximately equal increments of current at regular intervals. An arbitrary interval of 3 minutes was used.

Dry cells $(1.5 \mathrm{v})$ were used as a source of external power. The test electrode (cathode) was maintained at the desired potential by applying a constant voltage between the cathode and the auxiliary anode. The voltage was obtained from a variable voltage divider connected across the dry cell. The voltage was adjusted to provide the required current, which was measured with a zero-resistance milliammeter. Thus, the amount of current flowing to the cathode depended on the potential of that electrode. A change in chemical polarization of the cathode affected the applied current in such a way so as to oppose that change. The auxiliary anode was comparatively unaffected by anodic polarization at the desired current, and the cell resistance was relatively constant. Current and potential measurements were made approximately every 48 hours. The protective potential, in general, was maintained within $\pm 15 \mathrm{mv}$. All potential measurements were made by the Hickling interrupter method as adapted for use with soils [9].

\section{Protection Obtained by Maintaining a Fixed Potential}

The degree of cathodic protection that was obtained by maintaining the potential of the cathode at $-0.77 \mathrm{v}$ with respect to the saturated calomel electrode is indicated by the weight losses given in table 2. The weight losses of the cathodes attributable to the freely corroding period have been deducted from the losses shown in the table. Because the potentials of nearly all the cathodes departed more or less from the critical potential of -0.77 $\mathrm{v}$ for different periods of time, the extent of the departures with respect to potential and time are given in table 2 . It will be observed that the weight losses of the cathodes in all the soils are small compared with the weight losses of the controls, expecially of those cathodes whose potential deviated little, if at all, from -0.77 v. As may be expected, the results summarized in table 2 show that larger weight losses for any given soil are associated with the greater deviations less negative than the critical potential $(-0.77 \mathrm{v})$. Figures 3 and 4 show some of the cathodes and their corresponding controls for which data are included in table 2 . Some of the corrosion shown in the photographs of the protected specimens of course occurred during the freely corroding period of 48 hours. The fact that corrosion was not completely prevented in any of the soils is consistent with the results of Mears and Bialosky [10] who reported small residual weight losses for cathodically protected specimens. These investi- 


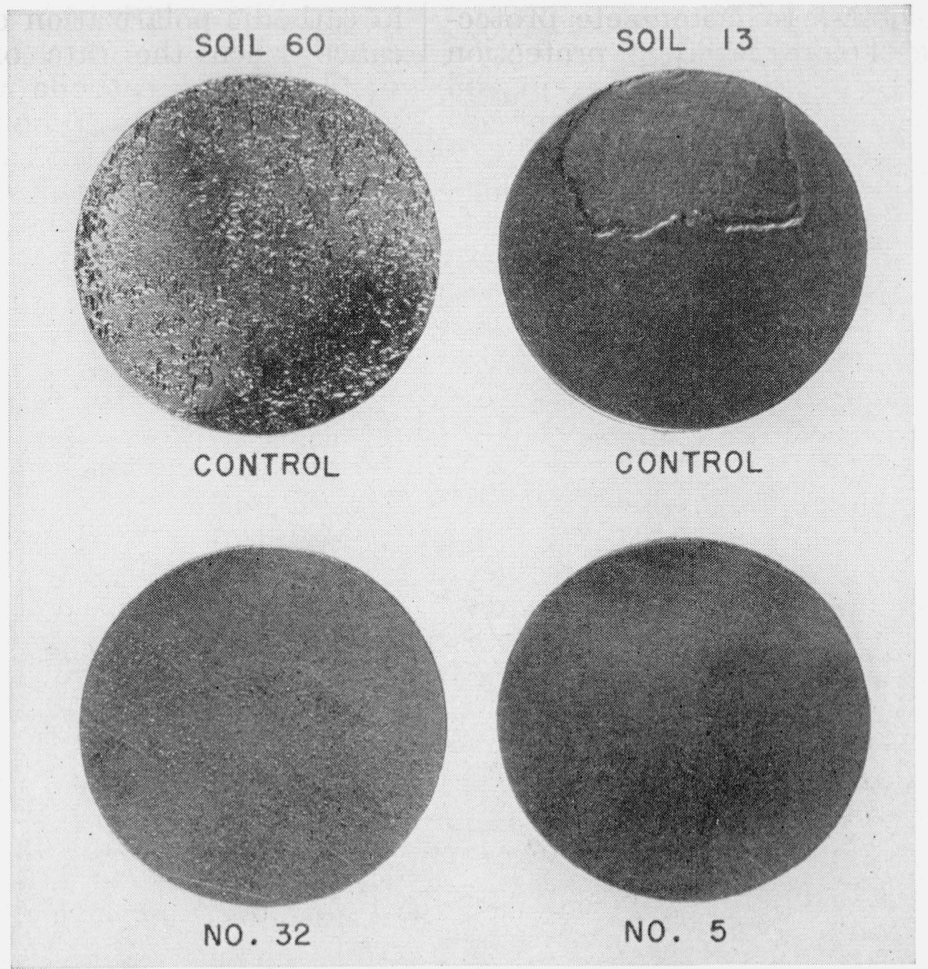

Figure 3. Unprotected (control) and protected steel electrodes in soil $60(\mathrm{pH} 2.9)$ and soil $13(\mathrm{pH} 9.5)$-exposure 60 days.

Protected cathodes 32 (soil 60) and 5 (soil 13) were maintained at potential $-0.77 \mathrm{v}$ (saturated calomel scale) after $48 \mathrm{hr}$ without protection.

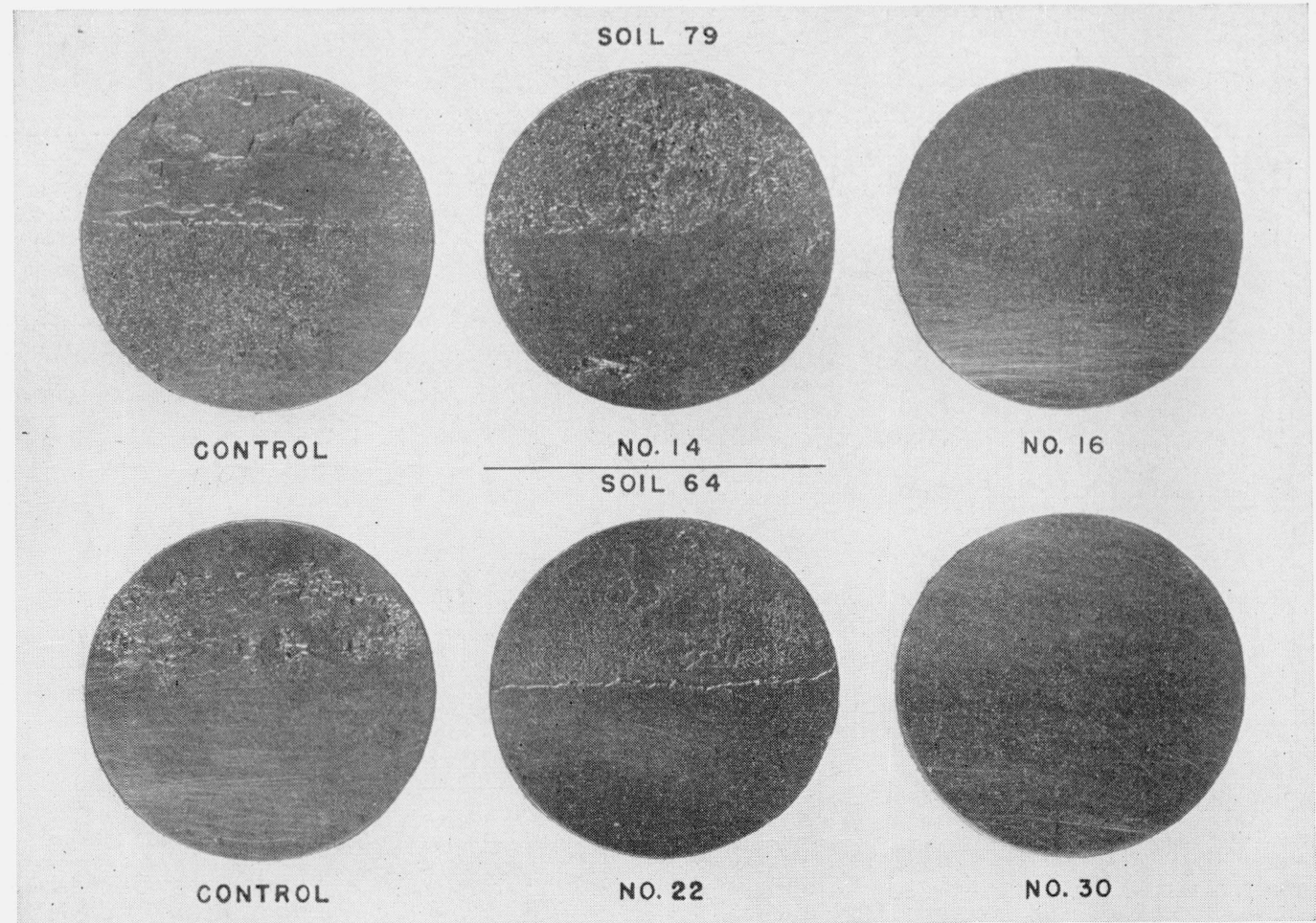

Figure 4. Effect of potential in cathodic protection-exposure 60 days

Partially protected cathodes 14 (soil 79) and 22 (soil 64) failed to polarize. Protected cathodes 16 (soil 79 ) and 30 (soil 64 ) were maintained at $-0.77 \mathrm{v}$ (saturated calomel scale) after $48 \mathrm{hr}$ without protection. 
gators attributed such losses to incomplete protection during the period before cathodic protection became wholly effective. The weight loss in soil 60 of a cathode having a somewhat different potential $(-0.69 \mathrm{v})$ than the critical potential $(-0.77 \mathrm{v})$ for 12 of the 60 days was $84 \mathrm{mg}$ (table 2 -cathode 1 ), while a change to only $-0.75 \mathrm{v}$ for 18 of the 60 days resulted in a weight loss of $40 \mathrm{mg}$ (table 2cathode 32). However, the weight loss accompanying a greatly increased potential (in a negative direction) to $-1.0 \mathrm{v}$ for almost the entire 60 days was $27 \mathrm{mg}$ table 3 -cathode 2 ), which is not materially less than that for cathode 32 . These results indicate that corrosion cannot be entirely prevented and that $-0.77 \mathrm{v}$ is the approximate optimum protective potential.

This is in accord with Kuhn's statement that polarizing an iron structure to potentials greater than $-0.85 \mathrm{v}\left(\right.$ ref. $\mathrm{Cu}-\mathrm{CuSO}_{4}$ ) represents wasted electric energy [1]. How much IR drop is included, if any, in the designated potential of $-0.85 \mathrm{v}$ cannot be definitely stated. (The value of $-0.77 \mathrm{v}$ referred to saturated calomel, which is free of IR drop outside of the electrical boundary, is equivalent to $-0.85 \mathrm{v}$ referred to a copper-copper sulfate reference electrode apart from any equivalent IR drop).

TABLE 2. Weight losses of cathodes maintained at approximately $-0.7 \% v$ (referred to saturated calomel) for 60 days

\begin{tabular}{|c|c|c|c|c|c|}
\hline \multirow[t]{2}{*}{$\begin{array}{c}\text { Soil } \\
\text { number }\end{array}$} & \multirow[t]{2}{*}{$\begin{array}{l}\text { Cathode } \\
\text { number }\end{array}$} & \multicolumn{2}{|c|}{$\begin{array}{l}\text { Weight loss of } \\
\text { electrodes }\end{array}$} & \multicolumn{2}{|c|}{$\begin{array}{l}\text { A verage potential } \\
\text { of the cathodes } \\
\text { during the peri- } \\
\text { od of departure } \\
\text { from }-0.77 \mathrm{~V}\end{array}$} \\
\hline & & Cathode & Control & $\begin{array}{c}\text { Days of } \\
\text { departure }\end{array}$ & $\begin{array}{l}\text { Poten- } \\
\text { tial }\end{array}$ \\
\hline $\begin{array}{l}13 \\
64 \\
78\end{array}$ & $\begin{array}{r}5 \\
30 \\
19\end{array}$ & $\begin{array}{r}m g \\
8 \\
6 \\
19\end{array}$ & $\begin{array}{l}m g \\
431 \\
196 \\
111\end{array}$ & $\begin{array}{l}0 \\
5 \\
3\end{array}$ & $\begin{array}{r}v \\
-0.77 \\
.76 \\
.75\end{array}$ \\
\hline $60 \ldots$ & $\begin{array}{r}32 \\
1\end{array}$ & $\begin{array}{l}40 \\
84\end{array}$ & $\begin{array}{l}519 \\
519\end{array}$ & $\begin{array}{l}18 \\
12\end{array}$ & $\begin{array}{l}.75 \\
.69\end{array}$ \\
\hline $\begin{array}{l}79 \\
79\end{array}$ & $\begin{array}{l}16 \\
13\end{array}$ & $\begin{array}{l}19 \\
28\end{array}$ & $\begin{array}{l}364 \\
364\end{array}$ & $\begin{array}{r}7 \\
14\end{array}$ & $\begin{array}{l}.74 \\
.69\end{array}$ \\
\hline
\end{tabular}

\section{Interpretation of Cathodic Polarization Curves in Cathodic Protection}

Breaks in cathodic polarization curves have been interpreted by Ewing [11], Pearson [12], Denison and Romanoff [13], and Holler [7] in terms of the current and potential requirements for cathodic protection in soils. However, the data pertaining to significant changes in potential or current noted by these investigators have been based chiefly on theoretical considerations. Also, the effect of time on chemical polarization as related to critical current densities has received scant attention. Limitations of polarization curves in certain environments for determining the current required for cathodic protection have been pointed out by Mears and Bialosky [10]. These investigators concede that breaks in cathodic polarization curves have definite significance when the rate of corrosion is determined wholly by the cathode reaction (cathodic control). For the special condition that the observed potential of a corroding metal is the same as that of the anode on open-circuit the break in the curve indicates that the entire surface has become cathodic. However, under most natural environmental soil conditions, the potential of iron with respect to a standard reference electrode is considerably less negative than the potential of iron in the same environment with air excluded. For such natural conditions the significance of breaks in cathodic polarization curves with respect to cathodic protection is not so readily understood.

In a study of the polarizing characteristics of dissimilar metals, Brown and Mears [14] showed that breaks in a composite cathodic polarization curve of a series of metals connected together in an electrolyte coincided with the open-circuit potential of the more anodic metal. Hence, in a differential aeration cell, a break in the cathodic polarization curve would be expected to occur at the open-circuit potential of the anode. Experimental verification of this was obtained with a corrosion cell set up similar to those already described, except that the electrode was cut into equal segments that were separated to permit measurement of the cell current. Figure 5 illustrates the electrical relations that were observed. It will be noted that a change in the polarization rate occurred around the open-circuit potential of the

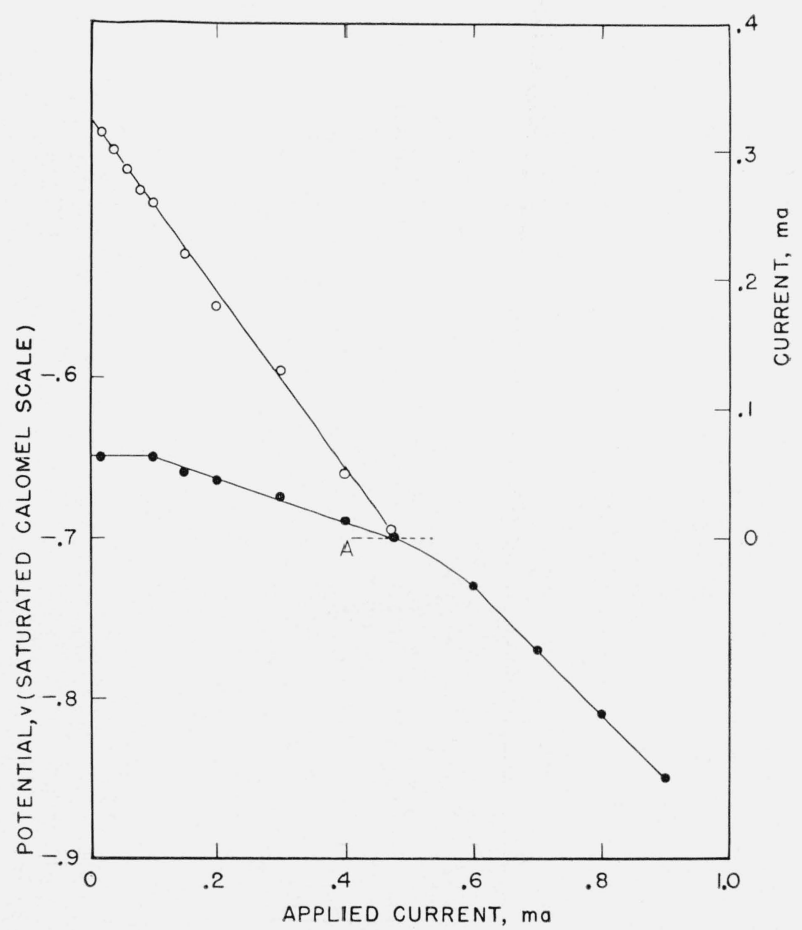

Figure 5. Current and potential relations of separated steel electrodes in a differential-aeration cell during cathodic polarization.

$\bigcirc$, Cell current; - couple potential; $A$, open-circuit potential of anode $=$ 
anode, namely, $-0.70 \mathrm{v}$, at which potential the cell current was reduced to zero. Because the potential of $-0.70 \mathrm{v}$ was the average potential of a large number of local couples on the anode, polarizing the couple to this potential would not eliminate local couples whose potentials were greater (more negative) than $-0.70 \mathrm{v}$. In order to effectively inhibit corrosion it would have been necessary to increase the potential of the experimental couple to $-0.77 \mathrm{v}$.

Typical cathodic polarization curves obtained on the solid electrode of one of the experimental cells, plotted on both rectangular and semilogarithmic coordinates are shown in figure 6 , a, and $b$, respectively. Two breaks are indicated in figure 6, a; point $A$ corresponding to the average open-circuit potential of the anode of the cell, and point $B$ corresponding to the beginning of the hydrogenovervoltage portion of the curve. An approximation of the current indicated by $A$ (fig. 6, a) is obtained from the semilogarithmic curve (fig. 6, b) by the intersection of the extended dashed straight-line portions of the curve. The straight-line part of the semilogarithmic curve at currents greater than the extrapolated value represents the hydrogen overvoltage. The beginning of the hydrogen-overvoltage curve does not always appear as a distinct break $(B)$ in the rectangular plot but sometimes appears as a gradual decrease in the polarization rate. Although the current indicated by $A$ (fig. 6, a) would not be sufficient initially to eliminate all local corrosion on

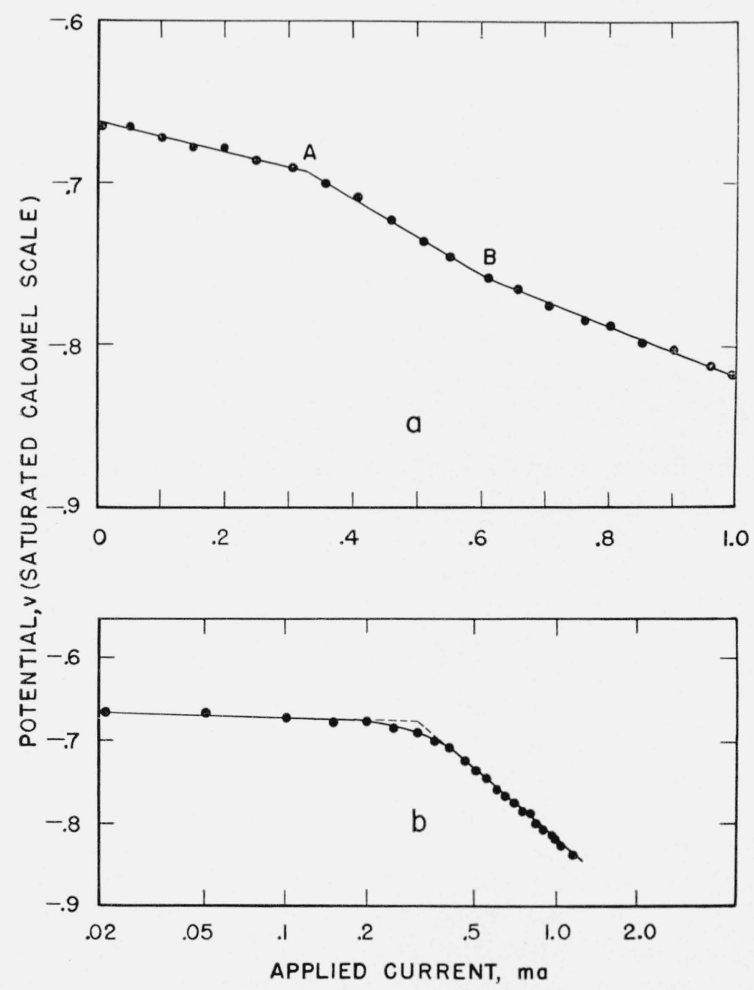

Figure 6. Cathodic polarization curves of a single steel electrode in a differential-aeration cell, (a) plotted on rectangular coordinates, (b) on semilogarithmic coordinates. the surface of an electrode it is reasonable to expect that the drift in potential caused by the continuous application of the current indicated by the break would be sufficient to polarize the surface to the protective potential and thereby to provide cathodic protection.

In order to determine the effectiveness of the current indicated by the break $A$ (fig. 6 , a) as a requirement for cathodic protection, corrosion cells were set up as described in section 4 , and currents indicated by the breaks $A$ in the cathodic polarization curves for the five soils studied were applied to the previously weighed cathodes. In four of the soils the cathode potentials drifted to the protective value of -0.77 $\mathrm{v}$ in from 3 to 21 days (table 3 ). The cathodes of two of these cells were allowed to drift to potentials greater than the protective potential, whereas the cathodes of the other two cells were maintained at -0.77 v. A comparison of weight losses of the cathodes with losses of the respective control electrodes (excepting in soil 64 , which will be discussed later) shows that the degree of protection is good. The data for cathode 6 furnish additional evidence that polarization to a potential greater than -0.77 $\mathrm{v}$ produces no appreciable further reduction in weight loss. This will be noted by comparison with the data for cathode 5 in table 2 , in which case no actual benefit is indicated. Cathode 2 has already been referred to in section 5 in this same connection.

The rapid drift in potential of cathodes 2, 21 and, 25 (table 3 ) to the protective value is consistent with the low weight losses of these electrodes. On the other hand, electrode 6 , exposed to the very corrosive soil 13, lost negligible weight in spite of the fact that its average potential $(-0.72 \mathrm{v})$ for 21 days was considerably less negative than the protective potential. This apparent anomaly is to be explained by the fact that local corrosion in soil 13 is generally negligible. The relative absence of local corrosion is well illustrated by comparing the photographs of the control electrodes (soils 13 and 60 ) in figure 3 . However, even in alkaline and well aerated soils such as soil 13, the possibility of pitting cannot be ignored. Should air be totally excluded from the surface of steel in such soils, polarization to the protective potential would be required.

TABLE 3. Potential changes and weight losses of cathodes receiving current indicated by the break in cathodic polarization curves - exposure 60 days

\begin{tabular}{|c|c|c|c|c|c|c|c|c|}
\hline \multirow{3}{*}{$\begin{array}{c}\text { Soil } \\
\text { number }\end{array}$} & \multirow{3}{*}{$\begin{array}{l}\text { Cath- } \\
\text { ode } \\
\text { num- } \\
\text { ber }\end{array}$} & \multirow{2}{*}{\multicolumn{2}{|c|}{$\begin{array}{l}\text { Weight loss of } \\
\text { electrodes }\end{array}$}} & \multirow{3}{*}{$\begin{array}{l}\text { Poten- } \\
\text { tial at } \\
\text { the } \\
\text { break }\end{array}$} & \multicolumn{4}{|c|}{ A verage potential of the cathode ${ }^{a}$} \\
\hline & & & & & \multicolumn{2}{|c|}{$\begin{array}{l}\text { Less than } \\
-0.77 \mathrm{v}\end{array}$} & \multicolumn{2}{|c|}{$\begin{array}{l}\text { Greater than } \\
\quad-0.77 \mathrm{v}\end{array}$} \\
\hline & & $\begin{array}{l}\text { Cath- } \\
\text { ode }\end{array}$ & Control & & Days & $\begin{array}{l}\text { Poten- } \\
\text { tial }\end{array}$ & Days & Potential \\
\hline $\begin{array}{l}78 \\
79 \\
60 \\
13 \\
64\end{array}$ & $\begin{array}{r}21 \\
25 \\
2 \\
6 \\
22\end{array}$ & $\begin{array}{r}m g \\
5 \\
14 \\
27 \\
9 \\
119\end{array}$ & $\begin{array}{l}m g \\
111 \\
364 \\
519 \\
431 \\
196\end{array}$ & $\begin{array}{r}v \\
-0.69 \\
.71 \\
.74 \\
.72 \\
.73\end{array}$ & $\begin{array}{r}3 \\
7 \\
3 \\
21 \\
60\end{array}$ & $\begin{array}{r}v \\
-0.74 \\
.75 \\
.76 \\
.72 \\
.68\end{array}$ & $\begin{array}{r}57 \\
53 \\
57 \\
39 \\
0\end{array}$ & $\begin{array}{r}v \\
\text { b }-0.77 \\
\text { b. } 77 \\
1.00 \\
1.50\end{array}$ \\
\hline & & & & & & & & \\
\hline
\end{tabular}

a Potential referred to the saturated calomel half-cell. b Current reduced to maintain potential indicated. 


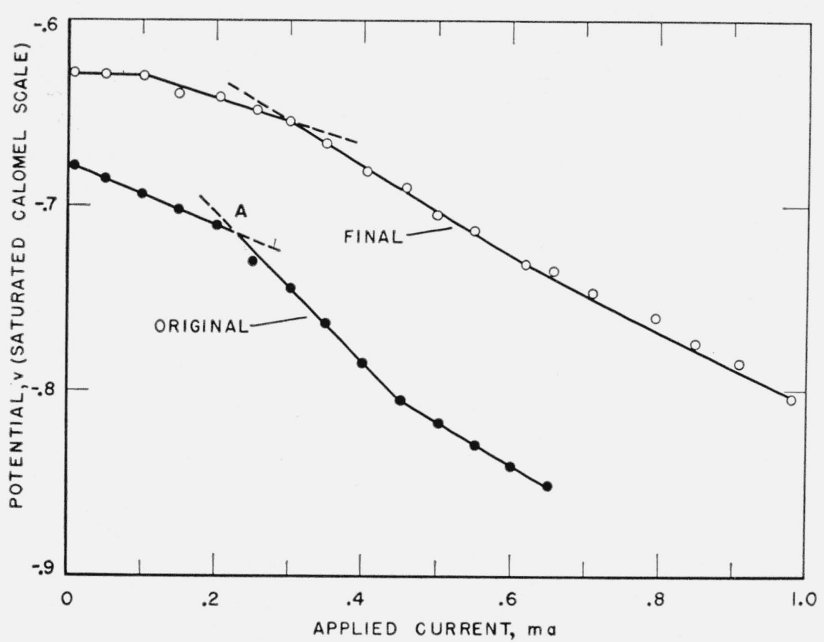

Figure 7. Cathodic polarization curves of a steel cathode (22) in soil 64 before and after the application of external current A for 60 days.

Protection was incomplete, as indicated by a weight loss of $119 \mathrm{mg}$ and reoccurrence of a break in the final curve. Note: In four of the five soils tested the current at A was sufficient to polarize the cathode and provide protection.

The fact that the potential of cathode 22 (soil 64) did not drift to the protective potential during the period of the test is not an indication that the current corresponding to the break in the cathodic polarization curve is insufficient for cathodic protection. The failure of the potential of cathode 22 to reach the protective value is attributed to selecting the applied current before the maximum rate of corrosion developed. Therefore, the current applied for cathodic protection was insufficient. The increase in the corrosion rate of cathode 22 during the course of the test is shown by the fact that the break in the cathodic polarization curve obtained at the conclusion of the test indicated a greater current requirement than the curve obtained at the beginning (fig. 7).

In maintaining the cathodes in the five soils at the protective potential the effect of chemical polarization resulted in a reduction of the applied current (table 4). In four of the soils a steady value of current, indicated as the minimum in table 4 , was reached in from 14 to 21 days after the current was initially applied. The reduction of current in the case of cathode 30 (table 4) although slight, occurred progressively over the 60-day period. Elimination of local couples by diffusion of alkali over the surface of this cathode progressed slowly because of the preponderance of soluble chloride in soil 64. It is probable that the applied current could have been reduced even more had the length of the test period been extended.

The average corrosion currents calculated from the weight losses of the control electrodes by the application of Faraday's law (table 4) indicate in most cases that the minimum current required for cathodic protection is about equal to the average current associated with corrosion. Thus, the high initial currents required for protection are partly attributable to the higher initial corrosion rates.

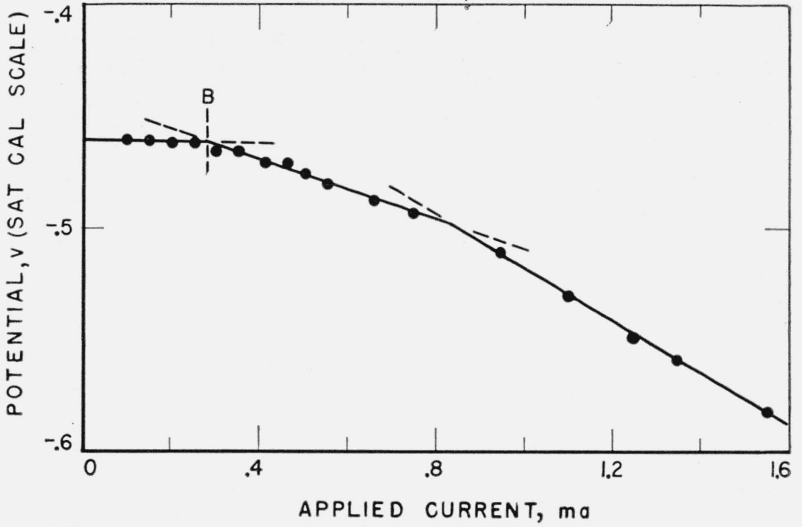

Figure 8. Cathodic polarization curve of a steel cathode (8) in soil 13 before the application of protective current. B, Minimum protective current, which maintained a cathode potential of $-0.77 \mathrm{v}$.

Denison and Romanoff studied the behavior of zinc-steel couples underground [13], and their results suggested that no more current is required for the cathodic protection of steel than that calculated by Faraday's law for loss in weight produced by normal corrosion.

TABLE 4. Current required for cathodic protection-exposure 60 days

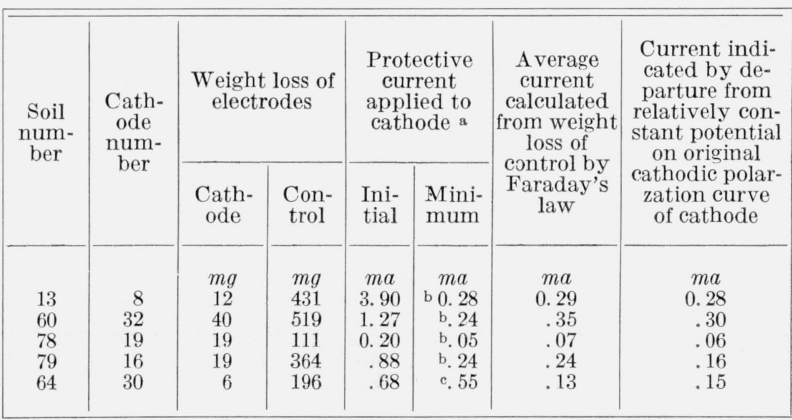

a Cathode maintained at $-.77 \mathrm{v} \pm 0.015 \mathrm{v}$ (referred to saturated calomel). b Minimum steady current after 14 to 21 days.

c Minimum current after a progressive decrease for 60 days.

At low values of applied current the potential of a corroding electrode is relatively constant (fig. 8). The currents at which the corresponding potentials depart from relativcly constant values are given in the last column of table 4 . For cathode 8 this value is shown at $B$ in figure 8 , which is characteristic of the curves used for obtaining the other values in the last column. In the case of the four cathodes that had stabilized after 21 days, there is fair agreement between the minimum current that actually maintained protection and the values in the last column. Apparently the point of departure on the initial cathodic polarization curve of the electrode potential from a relatively stable value, designates the applied current necessary to maintain a balance between the consumed and available oxygen after a cathodically protective alkaline film has been established on the electrode surface. 


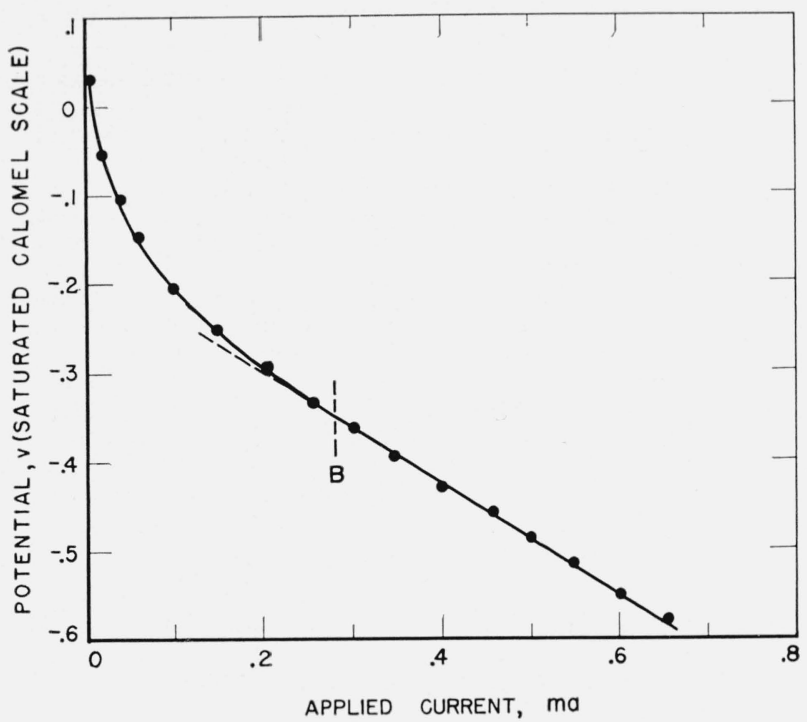

Figure 9. Cathodic polarization curve of cathode 8 in soil 13 (see fig. 8) after the application of protective current for 60 days.

B, Minimum protective current, which maintained a cathode potential of $-0.77 \mathrm{v}$. Weight loss $=12 \mathrm{mg}$

The close relation between the current required for protection and that associated with corrosion was probably applicable over the greater part of the 60 -day period, therefore suggesting that initially applied currents smaller than those indicated would not have been sufficient for protection. Consequently, the minimum current finally required for cathodic protection must not be confused with the current initially required. To verify this statement additional cells were assembled with soils 78 and 79 and the respective minimum currents, as indicated by the departure of cathode potentials from relatively constant values on the original cathodic polarization curves, were applied to the electrodes for the duration of the 60-day test period. The weight losses of these electrodes were as large as the losses associated with the corresponding controls. The potential of the cathode in soil 78 remained substantially unchanged during the test period while the potential of the cathode in soil 79 actually became less negative. The cathode in soil 79 (No. 14), together with the corresponding control, is shown in figure 4 . Field investigations in soils with pipe coupons show that a change in pipe potential to a more negative value is essential for a reduction in corrosion [15].

At the conclusion of the 60-day test period all cathodes were placed on open-circuit. After a period of about 15 hours, required for stabilization of the cathode potentials, a cathodic polarization curve again was obtained on each electrode. The curve for cathode 8 shown in figure 9 , is typical of all the curves obtained on the completely protected electrodes. The noble potential on open-circuit is due to the formation of an oxide film on the electrode surface. The polarization curve shown in figure 9 is typical of a true cathode and, of course, reveals

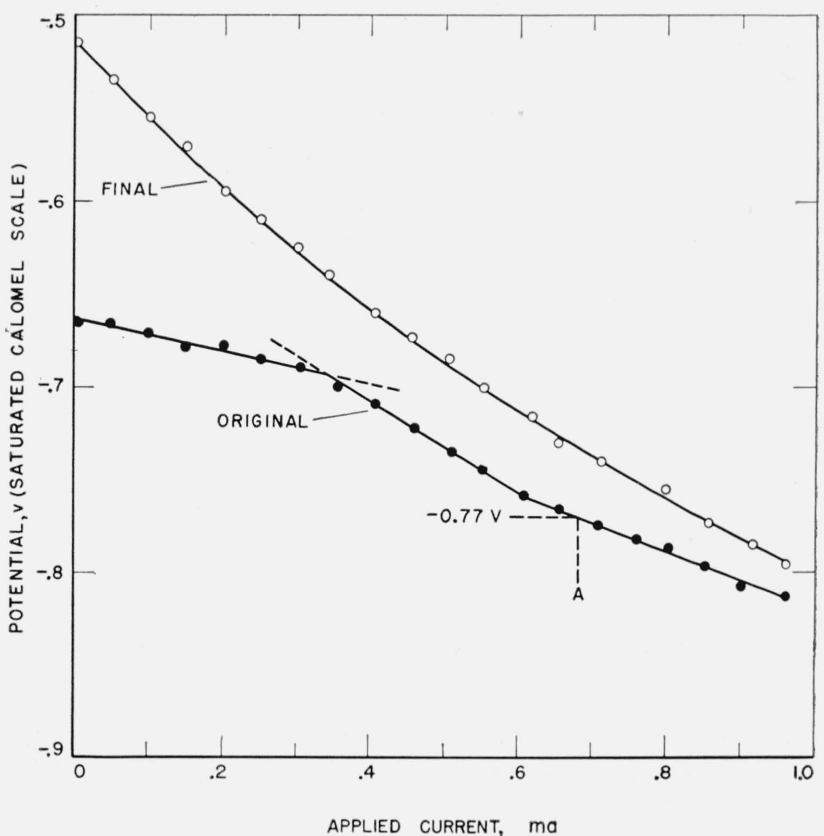

Figure 10. Cathodic polarization curves of a steel cathode (30) in soil 64 before and after the application of protective current for 60 days.

A, Current initially applied, subsequently varied, to maintain potential of $-0.77 \mathrm{v}$. Weight loss $=6 \mathrm{mg}$.

the absence of corrosion. It will be noted that, here again, $B$ denotes the minimum current required for protection and that an inflection occurs at this point. It cannot be ascertained whether this inflection has any significance, because it was not apparent on the final curves for all protected specimens (fig. 10). Here again in figure 10, the absence of a break in the final curve is consistent with the negligible weight loss that occurred on cathode 30 . The occurrence of a break, after having applied current for a period, shows that the current was insufficient for protection (fig. 7) or that a state of corrosion has been resumed. A photograph of cathode 22 on which the curves of figure 7 were obtained is shown in figure 4 .

\section{Summary}

The cathodic protection of steel in five corrosive soils was investigated in the laboratory, using a specially designed differential-aeration cell.

The most significant requirement for cathodic protection was found to be the maintenance of a critical potential on the surface of the cathode. This potential, defined by the point of intersection of the potential-pH curve for steel in air-free soils and the potential-pH curve for the hydrogen electrode at atmospheric pressure, was approximately $-0.77 \mathrm{v}$, referred to the saturated calomel electrode; or -0.53 $\mathrm{v}$ referred to the standard hydrogen electrode.

Electrodes maintained for 60 days at $-0.77 \mathrm{v}$ lost negligible weight under conditions that produced severe corrosion of unprotected electrodes simultaneously exposed in the same soils. 
Referred to the copper-copper sulfate electrode, the protective potential is approximately $-0.85 \mathrm{v}$, which is in agreement with the practice for cathodic protection used by many corrosion engineers, in those cases where the measurements are free of IR drop external to the electrical boundary of the corrosion circuit.

The current required to maintain the protective potential $(-0.77 \mathrm{v})$ diminished to fairly stable values after about 3 weeks for four of the five soils tested. This limiting value of current, which just maintains the protective potential, differs for different soils. These limiting values were in good agreement with the average current associated with the normal rates of corrosion of the unprotected electrodes.

A characteristic break in the cathodic polarization curve for steel in soil is interpreted as indicating the minimum current initially required for cathodic protection. Although the electrode potential corresponding to this current may be considerably less negative than the protective potential, it was found that the potential generally drifted to the critical protective value before appreciable corrosion occurred.

Cathodic polarization curves obtained for protected electrodes at the conclusion of the test were similar to those obtained for insoluble electrodes, thereby indicating that cathodic protection had been achieved.

\section{References}

[1] Robert J. Kuhn, Proc. Am. Petroleum Inst. 14, Sec. IV, 153 (Nov. 1933).

[2] R. B. Mears and R. H. Brown, Trans. Electrochem. Soc. \%4, 519 (1938)

[3] John R. Baylis, Ind. Eng. Chem. 18, 370 (1926).

[4] K. Murata, J. Soc. Chem. Ind. (Japan) 35, 532 (1932).

[5] Richard C. Corey and Thomas J. Finnegan, Proc. ASTM 39, 1242 (1939).

[6] O. Gatty and E. C. R. Spooner, The electrode potential behavior of corroding metals in aqueous solutions p. 310 (Oxford University Press, London, 1938).

[7] H. D. Holler, J. Electrochem. Soc. 97, 277 (Sept. 1950).

[8] J. M. Pearson, Trans. Electrochem. Soc. 81, 485 (1942).

[9] Robert B. Darnielle, J. Research NBS 25, 421 (1940) RP1336.

[10] R. B. Mears and J. M. Bialosky, Cathodic Protection Symposium, Electrochem. Soc. and Nat. Assn. Cor. Engrs. 37 (1949).

[11] Scott Ewing, Proc. Am. Gas Assn. 613 (1940).

[12] J. M. Pearson, Petroleum Engr. 15, 6, 7, 8 (1944).

[13] Irving A. Denison and Melvin Romanoff, J. Research NBS 40, 301 (1948) RP1876.

[14] R. H. Brown and R. B. Mears, Trans Electrochem. Soc. 81, 455 (1942).

[15] D. Holsteyn, Elec. News (Petroleum Ind. Elec. Assn.) 13, No. 3 (1943).

Washington, February 14, 1951. 